Methods of preserving the future supply are carefully considered, and a minimum size limit for fishes of economic importance during certain seasons is recommended. The crab fishery of the Lake has also been dealt with by the same authors ( $J$. Bombay Nat. Hist. Soc., 1952), and great credit is due to them for these two valuable reports.

\section{Scientific Observations on Heard Island in the Antarctic}

THE Southern Ocean-the ocean surrounding the Antarctic Continent-is divided into two main hydrological zones by the Antarctic Convergence, the line of demarcation at the surface of the ocean between the cold antaretic water and the warmer subantarctic water. The Ocean contains several isolated islands and groups of islands, including the following : South Georgia, South Sandwich Islands, Bouvetoya, Prince Edward Islands, Iles Crozet, Iles de Kerguelen, Heard Island, Macquarie Island, Campbell Island and Auckland Island. Differences in their altitudes, atmospheric circulation and ocean currents, combined with their positions relative to the Antarctic Convergence, have resulted in some of these islands being ice-covered and glaciated whereas others are clothed in grass and other non-arboreal vegetation. Heard Island (lat. $53^{\circ}$ S., long. $73 \frac{1}{2}^{\circ}$ E.), which lies about nine hundred miles north of the western sector of Australian Antarctic Territory, is a typical icecapped antarctic island. The recent establishment of a research station by the Commonwealth of Australia on Heard Island makes it possible to provide the first comprehensive scientific information on the geography, geology, meteorology, flora and fauna of the Island. This report has been prepared by P. G. Law and T. Burstall and issued by the Antarctic Division, Department of External Affairs, 187 Collins Street, Melbourne (Interim Report No. 7 ; pp. $32+$ 7 plates; 1953). It also contains accounts of recordings to extend studies in geomagnetism, seismology and knowledge of cosmic rays, as well as observations of the aurora australis.

\section{University of Birmingham}

The following have been appointed lecturers in the University of Birmingham: E. H. Wright (mechanical engineering), Dr. S. A. Barker (chemistry), Dr. K. F. Chackett (physics), C. B. Wright (physical metallurgy), Dr. J. D. Blainey (experimental pathology), J. B. W. Halley and K. R. Thornton (pathology), and Dr. N. S. Ross (Harry Payne lecturer in employer-employee relations). The following have been appointed to research fellowships: Dr. Jacques Vilain, Dr. P. D. Whitaker and E. A. Finlay (physics); Dr. O. Theander, Dr. A. Sykes, Dr. C. R. Patrick and M. Kapel (chemistry); Dr. E. L. Breese and Dr. F. W. Allard (genetics); J. R. Coope (geology); Dr. A. D. Hudson, Dr. Francine Gregoire and Dr. A. L. Woolf (pathology); Dr. P. B. Bradley (experimental psychiatry); and W. A. Coppel (pure mathematics). The following have resigned from the University: Dr. Hilde Behrend, research fellow in commerce, and J. S. Howell, research fellow in pathology. The National Coal Board has provided a sum of $£ 1,600$ for research in the Department of Mining of the University, and Unilever, Ltd., has made a grant to the Institute of Engineering Production of $£ 200$ a year for seven years towards expenses of the Institute. In the Department of Chemistry, 15,000 dollars has been provided by the Rockefeller Foundation for Prof. M.
Stacey's research in biochemistry, the amount to be spent over three years, and the Geigy Company has sponsored a research fellowship in the field of organic chemistry for one year.

\section{An nouncements}

Prof. R. E. GLover, professor of veterinary pathology in the University of Liverpool since 1949, and a past president of the Royal College of Veterinary Surgeons, has been appointed principal and dean of the Royal Veterinary College in succession to the late Prof. J. B. Buxton.

The Minister of Agriculture and Fisheries and the Secretary of State for Scotland have appointed Lord St. Aldwyn, joint parliamentary secretary to the Ministry of Agriculture and Fisheries, as chairman of the Myxomatosis Advisory Committee in succession to Lord Carrington. Dr. I. Thomas, deputy chief scientific officer to the Ministry of Agriculture and Fisheries, has been appointed a member of the Committee in succession to Dr. J. W. Evans (see p. 1130).

Lieut.-Colonel L. F. URwick has been awarded the Wallace Clark International Management Award for 1955. This Award has been given annually since 1948 by the American Society of Mechanical Engineers, the American Management Association, the Society for the Advancement of Management and the Association of Consulting Management Engineers, and is presented by the Council for International Progress in Management (U.S.A.), which represents the American management movement internationally. Colonel Urwick is the first British national to receive the Award.

UNDER the will of the late Francis Amory, the American Academy of Arts and Sciences is offering a substantial prize for outstanding work on some aspect of the alleviation or cure of diseases affecting the human reproductive organs, in particular those of men. Nominations, supported by statements of qualifications with regard to work done since 1947, should be sent as soon as possible to the American Academy of Arts and Sciences, 28 Newbury Street, Boston 16, Massachusetts.

T'He Institution of Naval Architects is offering the following scholarships for training in a university institution: I.N.A.-Elgar-Martell Scholarship, for naval architecture, worth $£ 275$ a year, which is open to British subjects less than twenty-three years old who have been employed for at least two years upon shipbuilding (entries close January 14, 1955) ; Denny Scholarships, one in naval architecture and one in marine engineering, worth $£ 175$ a year for four years at the University of Glasgow, with apprenticeship of five years, which is open to British subjects less than nineteen years old (entries close May 31, 1955). Further information can be obtained from the Secretary, Institution of Naval Architects, 10 Upper Belgrave Street, London, S.W.1.

A TELEGRAM has been received from Copenhagen announcing the discovery by Abell, at Palomar, of an asteroid on December 3. Its position was R.A. 7h. $08 \cdot 1 \mathrm{~m}$., Dec. $-21^{\circ} 19^{\prime}$; daily motion: in R.A. $-06 \mathrm{~m}$. 46s. ; in Dec. $-01 \cdot 25^{\circ}$; mag. 17 ; appearance stellar.

Erratum. In the article on "Chemistry of some Natural Pigments" in Nature of November 27, p. 990, col. 2, eight lines from the bottom, for ". . . introduced into tetramethyl tetrazaporphin . . ." read ". . . introduced into octamethyl tetrazaporphin ...". 